\title{
Christian Nadeau
}

Professeur, département de philosophie, Université de Montréal

\author{
(14 janvier 2010)
}

\section{"What justice after war? Elements for a theory of transitional justice."}

\author{
Un document produit en version numérique par Jean-Marie Tremblay, bénévole, \\ professeur de sociologie au Cégep de Chicoutimi \\ Courriel: jean-marie tremblay@uqac.ca \\ Site web pédagogique : http://www.uqac.ca/jmt-sociologue/ \\ Dans le cadre de: "Les classiques des sciences sociales" \\ Une bibliothèque numérique fondée et dirigée par Jean-Marie Tremblay, \\ professeur de sociologie au Cégep de Chicoutimi \\ Site web: http://classiques.uqac.ca/ \\ Une collection développée en collaboration avec la Bibliothèque \\ Paul-Émile-Boulet de l'Université du Québec à Chicoutimi \\ Site web: http://bibliotheque.uqac.ca/
}




\section{Politique d'utilisation de la bibliothèque des Classiques}

Toute reproduction et rediffusion de nos fichiers est interdite, même avec la mention de leur provenance, sans l'autorisation formelle, écrite, du fondateur des Classiques des sciences sociales, Jean-Marie Tremblay, sociologue.

Les fichiers des Classiques des sciences sociales ne peuvent sans autorisation formelle:

- être hébergés (en fichier ou page web, en totalité ou en partie) sur un serveur autre que celui des Classiques.

- servir de base de travail à un autre fichier modifié ensuite par tout autre moyen (couleur, police, mise en page, extraits, support, etc...),

Les fichiers (.html, .doc, .pdf, .rtf, .jpg, .gif) disponibles sur le site Les Classiques des sciences sociales sont la propriété des Classiques des sciences sociales, un organisme à but non lucratif composé exclusivement de bénévoles.

Ils sont disponibles pour une utilisation intellectuelle et personnelle et, en aucun cas, commerciale. Toute utilisation à des fins commerciales des fichiers sur ce site est strictement interdite et toute rediffusion est également strictement interdite.

L'accès à notre travail est libre et gratuit à tous les utilisateurs. C'est notre mission.

Jean-Marie Tremblay, sociologue

Fondateur et Président-directeur général, LES CLASSIQUES DES SCIENCES SOCIALES. 
Cette édition électronique a été réalisée par Jean-Marie Tremblay, bénévole, professeur de sociologie au Cégep de Chicoutimi à partir de :

Christian NADEAU

Professeur de philosophie, Université de Montréal.

"What justice after war?

Elements for a theory of transitional justice”.

Un article publié dans La vie des idées.fr, 14 janvier 2010.

[Autorisation formelle accordée par l'auteur le 20 février 2010 de diffuser cet article dans Les Classiques des sciences sociales.]

Courriel : christian.nadeau@umontreal.ca

Polices de caractères utilisée :

Pour le texte: Times New Roman, 12 points.

Pour les citations : Times New Roman, 12 points.

Pour les notes de bas de page : Times New Roman, 12 points.

Édition électronique réalisée avec le traitement de textes Microsoft Word 2008 pour Macintosh.

Mise en page sur papier format : LETTRE (US letter), 8.5’’ x 11’’)

Édition numérique réalisée le 25 février 2010 à Chicoutimi, Ville de Saguenay, province de Québec, Canada. 


\section{Christian Nadeau}

Professeur, département de philosophie, Université de Montréal

"What justice after war?

Elements for a theory of transitional justice".

Un article publié dans La vie des idées.fr, 14 janvier 2010.

Domaine : Philosophy

Tags : justice | droit | guerre

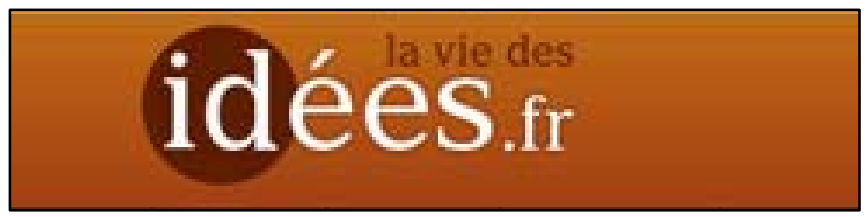

Is it possible, after a conflict or genocide, to deliver justice and build a new political order acceptable to all sides previously set on destroying each other? Christian Nadeau looks at recent conflicts in Rwanda and in the former Yugoslavia, among others, to lay down the foundations of a theory of transitional justice. In his view a successful transition to democracy has to be based on reparation and deliberation.

Jus post bellum, or post-war law, is a category of just war theory dealing with the moral considerations to be applied in the wake of conflicts. Transitional justice is generally considered as a legitimate response to systematic violations of human rights. It does not itself represent a special form of basic rights and liberties but instead corresponds to the efforts at justice-from the penal perspective or from the perspective of the equitable redistribution of resources-and at democratisation in the wake of major political crises.

The main thesis presented here relates to the normative value of a conciliation between two apparently opposed, even independent objectives, that of criminal justice and that of political reconstruction. On the one hand, jus post bellum poses the problem of the aftermath to conflict in legal terms and in terms of moral obligations, in particular in terms of penal sanctions against those guilty of crimes. On the other hand, transitional justice poses the problem of finding a legitimate and 
acceptable outcome to conflict for all involved. Jus post bellum and transitional justice are not mutually contradictory normative entities, but quests for justice and requests for reparation in the wake of mass crimes committed during war, on the one hand, and efforts at democratisation and political equilibrium at the moment of transition, on the other, sometimes act in opposite directions and prove mutually harmful. The question, then, is whether a choice must be made between justice and democracy. If yes, in which cases, and if no, how can a satisfactory, balanced theory be elaborated that assumes the compatibility of these two normative registers ?

Our thesis is based on three main arguments. Firstly, the inherent difficulties of post-war transition periods require us to appeal to a special notion of responsibility, where group logic does not overpower individual logic, but whereby individual actions are only conceivable within social relationships. In other words, crimes committed during wars are both the responsibility of a group as a group, and of individuals. What is important here is to understand the interrelationship of individuals within a group, or of groups amongst themselves. Secondly, this complex notion of responsibility becomes clearer if we refer to theories of restorative justice. Finally, democratic deliberation is, to us, the essential link between the processes of democratisation and justice. A critical dialogue between parties affected by the conflict is the cornerstone of transitional justice. If this dialogue is well managed, it can ensure adequate coordination between political objectives and the legal obligations of transitional justice. As a consequence, deliberation should come into play within the context of restorative justice as well as during democratisation processes. It is also necessary to ensure that there be no primacy of reparation over democratisation, and that neither precede the other; each should extend into the other.

The aim of this article is to present a set of coherent moral arguments that have a place in a theory of transitional justice in a post-war context. The wars in question here may involve civil conflict, as in Rwanda and the former Yugoslavia, as well as wars between States, as in the Second World War. However, reconciliation measures will vary significantly depending on the type of conflict. 


\section{Normative issues}

Transitional justice and jus post bellum represent two distinct but compatible theories, meant to address the problems posed in the wake of civil or inter-State warfare. Transitional justice does not only refer to jus post bellum, which may be constructed without reference to the full set of normative notions composing the first.

By definition, approaches to jus post bellum comply with theories of just warfare (Nadeau, Saada, 2009; Walzer, 2006). Above all, jus post bellum provides an analysis of moral conditions at the end of war. However, a war may be declared officially over, even it continues on the ground. The official declaration of the end of the conflict in Iraq by President Bush in May 2003, as hostilities within in the country mounted in intensity in the months following, is one example. The notion of jus post bellum should thus be understood as what follows on from war, but also as what legitimately leads to the real end of war. Furthermore, jus post bellum does not only involve reviewing acts of violence committed during the warwhich is the domain of jus in bello-neither does it mean questioning the legitimacy of the war in the first place-which is the domain of jus ad bellum. Jus ad bellum represents the moral framework through which to consider the conditions for legitimately initiating war, whereas jus in bello designates a series of moral rules relating to the conduct of each side during war, for example the principle of civilian immunity.

Jus post bellum represents a separate category from theories of just war and cannot be reduced to the moral rules of the two other areas of law. It is however not independent. While within just war theory jus ad bellum and jus in bello are

traditionally viewed as different entities, many contemporary theorists advocate a transversal interpretation of the moral norms befitting each jus. This is especially true of jus post bellum: commentators concur in showing its dependency with regard to the two other modalities of conflict law.

This dependency is not synonymous with repetition. Of course, post-war justice must assess violations of jus ad bellum and jus in bello. But it is perfectly pos- 
sible that a conflict should take place for a just cause, in conformity with jus in bello, without the winners of this legitimate war subsequently manifesting moral respect of the defeated. It goes without saying that there has not been a war to this day that has presented, for at least one of the parties present, a satisfactory record of conduct in respect of the rules of jus in bello. We may suppose that even if such were the case, it would change nothing of the argument according to which a war can be fought for a just cause, in a manner respecting the law of international conflict law, and without the winning State having any obligation towards the vanquished State. In the case of a civil war, where it is sometimes very difficult to identify the victims, the rules of war may have been respected but the aftermath of the conflict may be open to moral condemnation for various reasons that a special category of just war theories, the jus post bellum, must specify.

The notion of emerging from a crisis is also at the heart of transitional justice. It operates on a much broader level than that of post-conflict analysis, however. Many studies of transitional justice have focused on describing the problems related to the dismantling of the Soviet bloc. We also find transitional justice at the heart of the debates about the reconstruction of countries recently governed by dictatorships or repressive governments. Transitional justice may also appear as a series of measures aiming at forming an ad hoc tribunal for political crimes. Such has been the approach adopted recently by the Special Lebanon Tribunal requested by the Lebanese government at the United Nations in the wake of the political murder of Rafic Hariri, the former Prime Minister.

Transitional justice is also to be found in the debates surrounding deep constitutional changes and analysis of crimes committed in the name of the former regime. This is true the world over. Transitional justice is thus most often identified in truth and reconciliation commissions (B. Cassin, O. Cayla, P.-J. Salazar, 2004; Hazan, 2007), like those organised in South Africa after the abandonment of Apartheid policy, in South America (in Argentina, Chile, Guatemala, Panama, Peru, and El Salvador), in Africa (Morocco, Rwanda, Liberia, and Sierra Leone) as well as in South Korea, the Fiji Islands, and West Timor. However, commissions can also operate according to parameters that do not imply a strictly transitional process and in cases where there has not been war or the systematic use of military violence. In Canada, for example, the Truth and Reconciliation Commission, established in June 2008, was given the responsibility of investigating native 
boarding schools, whose mission had been to extract natives from their home community and integrate them by force into the Canadian social and cultural order. But in the majority of countries, these commissions intervene following a process of constitutional change or in the framework of a major political transition, and for most of the States mentioned above, their first mandate has been to make an exhaustive analysis of crimes committed during civil or inter-state wars, as was the case in Sierra Leone, or during brutal and systematic political repression-we might cite the Comisión Nacional sobre la Desaparición de Personas in Argentina as an example.

While the stakes are high for truth and reconciliation committees in transitional processes, the majority of theoreticians and practitioners agree on the establishment of a global process, covering both problems of pacification, democratic transition and legal procedures relating to violent acts committed in the past. It is then important to describe the procedures for criminal proceedings, for dealing with massive violations of human rights, for economic and symbolic reparation programs (Torpey, 2006), for reinforced long-term security and pacification measures, as well as for commemorating tragedies.

In transitional contexts, the cohabitation of legal and political considerations is inevitable; consequently, the greatest challenge is to avoid the politicisation of the legal process, which would undermine the latter's impartiality. However, politics could benefit greatly from the legal process as long as the effects of legitimate equitable and restorative processes impose the same norms of transparency and equity as on the transitional process as a whole.

Finally, all these measures would have no meaning if they only applied to men. It is therefore necessary to pay particular attention to the women implied in the events, so as to avoid their becoming victims twice, firstly as victims of injustice and secondly as victims of discrimination. All of these measures have been adopted by several international organisations, in particular, the International Centre for Transitional Justice (http://ictj.org/en/). 


\section{International criminal justice}

Aftermaths of wars are always difficult periods. Not only does peace rely on a precious equilibrium between all sides, but old institutions require top-to-bottom revision, or must even be completely replaced. Jus post bellum and transitional justice imply the identification of abuse and crimes with a view to criminal proceedings, but also to the compensation and public recognition of victims. However, the extent of crimes resulting from a military conflict is such that it is inopportune to limit responsibility to the legal examination of crimes committed by individuals. The political and institutional systematisation of crimes requires a hybrid approach, based on both collective and individual responsibility. In order to do this, the theory that is required should neither be holistic-for such a vision of things would crush individual wills and would explain all acts as a function of social structures-nor atomistic - for criminal acts are never isolated from each other, especially in the context of war. It is thus essential not to substitute collective responsibility for individual responsibility, but to understand the social and political modes of the interrelations between the agents in question (Kutz, 2000).

After a conflict, legal and penal institutions are generally too instable to guarantee genuine justice. Even if, in the case of inter-State wars, the winner-State or coalition-has not suffered the same losses as the loser, post-war political instability make impartial judgment difficult. Finally international conflicts have less and less adopted a binary logic solely implicating two major powers. These various factors provide a strong argument for increasing the role of international penal justice.

Since the Nuremberg and Tokyo Tribunals - two founding international moments - international criminal justice has come a long way. Legal literature on the subject has now developed to such a point that it enables us to respond in a more satisfactory manner to requests for justice than when the international Tribunal for the former Yugoslavia or the one in Rwanda were formed. Much progress has yet to be made but some steps have been taken in the right direction. Among recent developments in international criminal justice we may note the increasing efforts at collaboration between international and local criminal justice systems. Since 
the Treaty of Rome and the establishment of an International Criminal Court in The Hague, there has been an international authority with jurisdiction over mass crimes such as genocides, crimes against humanity and acts of aggression. But the international penal justice system has been the subject of criticism. Ultimately it only has jurisdiction over those countries that have signed the Treaty. An emergency request from the UN Security Council can also lead to the accusation of non-signatory States. The Security Council also has the power to suspend proceedings which limits the Court's authority. Furthermore, the Court only takes action after States have failed, i.e., when they are in no position to pass justice in their own way. Despite the efforts of the International Criminal Court, this significant progress in international law is therefore still subject to the authority of the most powerful States (Eisikovits, 2009).

We can now better understand the idea according to which all attempts at justice following an armed conflict can only lead to justice for the winners. To this we may reply, in line with Gary Bass's work, that while only the victory of the attacked side over the attacking side can make justice possible, only the equity of the process can guarantee that there is indeed justice and not vengeance. (Bass, 2002).

Another criticism is that the international criminal justice system does not have the same legal basis as local criminal justice systems. If this is the case, the definition of a crime becomes harder to make. Some acts may be reprehensible from a moral but not a legal standpoint, unless the traditional rule is broken that there can be no crime when the law does not condemn the act (nullum crimen, nulla poena sine lege). In addition, accepting the superiority of international law to the political and judicial authority of the State in question calls into question the very principle of sovereignty. In contrast, in the case of interstate conflicts, the very act of aggression prevents the attacker, if defeated, from having recourse to the principle of sovereignty, because the invasion demonstrates a violation of the sovereignty of others. Finally, assuming the international legal standard prevails, it could be interpreted as a new law, which raises the problem of retroactivity. But here too, the latest developments in international criminal law show an understanding of such problems through an appeal to the standards of natural law; here, an act can be a crime even if it is not defined as such in law. 
This does not resolve the problem of selectivity, in the sense that the same standards of law are not applied equitably to all, for only higher authorities are judged, leaving subordinates free. While decision makers are responsible for decisions leading to crimes, subordinates, who are greater in number, make sure these actions are effective (Eisikovits, 2009).

The final criticism of the international criminal justice system is crucial. It is considered as function of a model of individual responsibility that isolates actors so as to identify the unique role of the individual judged. In any criminal action leading to an investigation of the history of the crime including extenuating circumstances, even if only partial, it is however difficult to provide an overview of war crimes or mass crimes systematically organized by a political body through the repeated examination of individual cases. However, the individual responsibility of higher authorities must absolutely be maintained, on the condition that no absolution is offered to the subordinates of criminal orders. What is therefore necessary then is a different conception of political responsibility that is more sensitive to the phenomena of collective action.

\section{Restorative justice}

The criminal justice system and the retributivist model, focussing on the necessity for punishment or of sanctions does not respond satisfactorily to the requirements of transitional justice, in particular in the post-war context. It is common to make a distinction between the deontologist and consequentialist conceptions of criminal justice. In the first, retribution is one of the main variations and supposes that the sentence is deserved by the offending party. The only goal of the sentence is to sanction the crime. The second sees the punishments among a set of measures aiming at guaranteeing the respect of social norms in view of a social equilibrium. The danger is therefore to instrumentalise sentencing according to goals independent of justice Guillarme, 2003). For this reason, the active authorities within transitional processes, like governments, appeal to the restorative justice model (Sullivan, 2008). According to John Braithwaite, restorative justice sets out to be both a response to the harm caused by the crime and a collective investigation into what the crime reveals, about the criminals themselves but also about 
the community to which they belong (Braithwaite, 2002). Restorative justice is clearly of consequentialist inspiration, but responds to the criticism of instrumentalisation by advocating a selection of safeguards against such aberrations. At the heart of these measures is the idea of a deliberation between those directly involved. There exist several variations on the subject of restorative justice, but according to Braithwaite, most writers agree with Tony Marshall’s proposed definition: "Restorative justice is a process by which all parties having a relationship to a crime join together with a view to collectively resolve problems raised in the wake of the violence” (cited by Braithwaite, 2002, p. 11). Compensation therefore supposes moral demands in respect of the criminal parties, but also in respect of the victims. These demands are clearly not of the same order.

The different criticisms of the strictly retributivist conception of international criminal justice pleads in favour of a complementary approach, that of restorative justice. Either this approach effectively replaces retributivist justice, which seems dangerous and improbable to us, especially in a post-war context, or it can be thought through in a complementary way, which we shall specify. This means that restorative justice should be approached in parallel to criminal justice, which focusses on sanctions. We are facing a hybrid conception of reparation. The defence of this approach cannot be made here, but it is possible to see how, if presented in a satisfactory and coherent way, such a hybrid approach would be able to respond to the criticism outlined earlier. It would also allow for easier concordance between the transitional processes of reparation and those of pacification and democratisation, because of the central role accorded to the deliberation between parties. It must be emphasized that the deliberation model is the theoretical heart of transitional justice provided that it is grasped in a global way. Founded on the idea of a necessary mediation between parties, the process of restorative justice places, as a starting point to justice, a relationship of deliberational exchanges between the parties involved in the conflict. These exchanges are necessarily governed by democratic principles, without which they would be null and void. As a consequence, if the foundation of legal procedures is based on democratic deliberation, from the outset they will avoid opposition with democratic processes. They will, on the contrary, be the instigators of democratic processes.

One of the most famous instances of restorative justice is the truth and reconciliation commission model, which was discussed earlier. This model presents 
undeniable advantages, because it grants an essential value to victim testimonies, which is crucial for their recognition, on the condition that requests for recognition not be obligatorily accompanied by sanctions, which would require an independent procedure to examine the validity of such a requirement. The motivations behind testimonies need to be determined to assess how they fit into the process of, if not, reconciliation in its strongest sense, then at least collective reparation in view of the transition towards justice and democracy. It is important to avoid disqualifying testimony on the basis of the witness's group affiliations. Thus in the case of an examination of the conflict opposing Serbs and Croats during the 19911995 war, privilege accorded the testimonies of Croats could be highly prejudicial to both the establishing of facts, but also at efforts at reconstruction. Once again, the objectives of genuine justice cannot be obtained if procedures are not equitable.

Restorative justice can also lead to an impasse if it leads to an amnesty or impunity, and, ultimately, to the de-responsibilisation of parties. In this case, deliberation will act against justice and against itself, as the denial of justice would lead necessarily to resentment and, subsequently, to the refusal of all new dialogue once the basis of trust has been lost. This is why deliberation with restorative objectives requires the internal constraints we have discussed, and external constraints, which should be the responsibility of international criminal justice-hence the need for a hybrid conception of criminal justice-and transitional movements parallel to criminal justice reform, like efforts at democratisation, which we will look at shortly.

All these measures could be associated with the Kantian principle of publicity, or more generally with that of transparency. There can be no precise interpretation of the nature and scope of crimes without a precise evaluation of the background context and the conditions of action. If even the institutions necessary to transitional societies are instable or nascent, they will have no chance of success with the publicity criteria. Furthermore as transitional processes are mainly supervised by foreign and international institutions and organisations, these institutions and organisations can monitor whether requirements for transparency are satisfied, on the condition that they too subscribe to them. Finally one of the roles of civil society will be precisely to observe and require this transparency as far as possible. 
This is the reason for which freedom of expression is an absolute condition of the transitional process; the same applies to the right to information.

In debates following conflicts, and at the moment reparation is requested, a form of social deliberation should be encouraged even if it can give rise to considerable tension. If peace is sought at all costs, it can lead to considerable resentment, which could in turn spark new violence. This is as valid for the transitional processes after civil wars as for the transitional processes after wars between states. This deliberation is crucial as it represents one of the main intersections between the aims of justice and those of pacification and democratisation.

\section{Deliberation and the formation of institutions}

The mechanisms specific to deliberative democracy in the context of a wellordered society, or even a mixed society-where opposition to authority is both violent as well as channeled through democratic proceedings (Tilly, Tarrow, 2008) - have difficulty responding to the normative requisites of theories of deliberative democracy, whether of Rawlsian or Habermasian inspiration (Leydet, 2002). According to these theories, the exchanges between discussion partners should satisfy certain norms like those of transparency or reciprocity. If these requisites seem too demanding for well-ordered societies, does this mean the deliberative model in the framework of transitional processes is doomed from the outset? By no means.

To begin with, deliberation is inevitable to ensure the stability of institutions, even if it can give rise to new crises and previously non-existent polarities. Indeed, unless democratisation and justice is imposed via strong-arm tactics, which would be absurd - even though this has been attempted in the past - the relationship between the formerly conflictual parties is an indispensable bridge to cross, and requires the examination of crimes to be able to genuinely emerge from the conflict. Secondly, deliberation ensures, if it is maintained according to certain parameters, a constant reassessment of the civic relationship of agents in respect of the social bond, which is the very source of the dynamics that all transitional processes require. 
Deliberation does not prevent, and should not prevent a certain type of conflict between parties. Dissensus is necessary as it enables self-surveillance among agents, similar to 'checks and balances' mechanisms. What has to be avoided is a simple imbalance of power leading to the defeat of the weakest (Dryzek, 2006, chap. 3).

Deliberation should despite everything have an end, not in itself, but when it means taking a decision (Goodin, 2008). In the case of transitional societies, the voting procedure, otherwise effective, seems very unlikely. However, where possible it should be employed so as to prevent deliberation from hindering, rather than stimulating, the efficiency of the transitional process.

It is however difficult to envisage a procedure of deliberative democracy in a transitional context, for the simple reason that democratic institutions cannot be completed without first existing, that is to say without presenting a certain stability. Deliberation can follow a transitional process, but it is also the latter's precondition. In this sense, we could speak of deliberative democratisation. This process could be broken down into three successive logical, rather than chronological, parts:

1) Deliberation must be verified within the mechanisms of transitional justice. It is the locus for testimony but also for the investigation and verification of evidence.

2) Deliberation encourages the archiving of facts and the construction of a civic memory. There will necessarily be critical dialogue between historians and the protagonists of conflicts, whose memory will be submitted to historical examination. Directed towards the past, memory is also about looking to the future, as it records acts to inscribe them in the long term.

3) Deliberation brings with it the principle of the minimal respect of others and reciprocity. It works in a dynamic way so as to consolidate the parallel efforts at democratisation - the creation of institutions and legal norms specific to the democratic model advocated by a given society-but also at a civic entity of surveillance, both in respect of democratisation and of all transitional processes. It enables a society to oversee the political and legal model elaborated for it. Seeing as all these social actors do not participate in the same way, even if they have equal rights, in the creation of new ins- 
titutions, it is necessary for them to be in a position to monitor and control what could act counter to their fundamental rights and interests. This may be necessary for institutions in their early stages, or later in the transitional process, for example when the moment of defining what kind of civic and historical education will be offered to new generations, or when commemorative sites are created, such as civic monuments.

The fact remains that deliberation should rest on a minimalist vision of social cohesion and cooperation. In other words what is required is not a community of strong but minimal values, which would then ensure the re-composition of the social bond, without ever threatening a plurality of values. Any attempt running counter to pluralism will exacerbate social tensions without taking advantage of the dynamism of conflicts.

Transparency is a vital condition for trials as well as for deliberations focussing on reparations. The same applies to democratisation, which should be verifiable in the deliberation mechanisms themselves, and in everything relating to the issues of deliberation. Without transparency, individuals progress blindly in their exchanges, which undermines trust and prevents cooperation.

The coordination of the processes of peace, justice and democratisation implies the participation of all sides involved. This is the reason for which emerging institutions should ensure that public criticism of legal and political decisions can be made freely, hence the importance of free and independent media. Public financing of media should be among the priorities of transitional governments; media should be left total freedom. It is also important to encourage the work of international organisations. One of the strengths of these organisations is to be able to denounce attempts at the dissimulation of information.

\section{CONCLUSION}

What role does research into the normative foundations of transitional justice and jus post bellum have? Like every analytical approach of this kind, the aim above all is to clarify and to understand the practical and moral issues that already exist relating to war and the modes of transition towards democracy, particularly 
in respect of international laws. These norms that have been institutionalised or are in the process of being institutionalised, can however be completed and unified in a global theoretical discourse, enabling better understanding of the important connections between legal and political categories that appear independent. Ultimately, the aim is to influence, via a philosophical approach and as much as possible, the construction of new parameters of international criminal justice, as well as the work of legal and political reconstruction specific to States and political communities.

In a recent book devoted to transitional justice, Jon Elster warns against a theoretical and normative interpretation of transitional justice. According to him, the phenomena of transition, observable at least since the French Revolution, do not fit into tight normative moral frameworks. These political phenomena are too closely connected to their emerging context to be subject to normative generalisation. However, he does admit that empirical descriptions of political transitions alone are not sufficient, as it is possible to see shared mechanisms through distinct political realities. Identifying these mechanisms, though, involves a lower level of abstraction than that required of a normative approach to transitional phenomena (Elster, 2004, p. 76-77). If it is only possible to generalise processes of transitional justice through classification and taxonomy and if we cannot explain these processes or their emergence through causal laws, how can we propose a set of normative parameters for transitions?

We can reply to this supposed limit of the theoretical approach - and a fortiori of the normative approach - with two counter-arguments. The first and easiest consists in saying that if it is true of transitional justice, it should also be true of the majority of political phenomena. But this argument, which Elster would probably accept, does not provide a suitable response, because it does not enable us to settle the question. Another more interesting response stems from the following, simple observation: it seems extremely difficult to avoid the evaluation of existing norms in transitional processes, precisely because they are norms and not raw facts. As a result, the evaluation of existing norms itself supposes a normative framework, not derived from analysis of facts, but in a direct interrelation with this analysis.

A theory of transitional justice understood as a hybrid theory involving social justice, reparation and democratisation cannot reduce moral demands to emotions 
or interests. Even if indignation before crimes committed by political authorities may wane over time, this does not undermine the legitimacy of demands for justice or the importance of efforts at democratisation (Luban, 2006). It goes without saying, however, that the evaluation of norms implemented in a transitional process must absolutely take into account, wherever possible, of all available facts. Hence, theory should not be imposed on the reality it intends to grasp, but be inspired by that reality. The evaluation of normative discourse will thus be tested by experience.

by Christian Nadeau [14-01-2010]

\section{Further reading}

\section{Sur La Vie des Idées :}

Le tirage au sort, plus juste que le choix rationnel. Entretien avec Jon Elster, par Florent Guénard \& Hélène Landemore [02-07-2008]

\section{Références bibliographiques :}

Gary Bass, Stay the Hand of Justice. The Politics of War Crimes Tribunals, Princeton, Princeton University Press, 2002, p. 329.

John Braithwaite, Crime, Shame and Reintegration, Cambridge, Cambridge University Press, 1989.

Barbara Cassin, Olivier Cayla, Philippe-Joseph Salazar (dir.), « Vérité, réconciliation, réparation », Le Genre humain, n 43, Paris, Seuil, 2004.

John S. Dryzek, Deliberative Global Politics: Discourse and Democracy in a Divided World, Londres, Polity Press, 2006.

Nir Eisikovits, « Transitional Justice », in Edward N. Zalta (dir.), The Stanford Encyclopedia of Philosophy, Spring 2009 Edition. 
Jon Elster, Closing the Books. Transitional Justice in Historical Perspectives, New York, Cambridge University Press, 2004, p. 76-77.

Robert Goodin, Innovating Democracy: Democratic Theory and Practice after the Deliberative Turn, Oxford, Oxford University Press, 2008. Bertrand Guillarme, Penser la peine, Paris, PUF, 2003.

David Hazan, Juger la guerre, juger l'histoire. Du bon usage des commissions Vérité et de la justice internationale, Paris, PUF, 2007.

Christopher Kutz, Complicity. Ethics and Law for a Collective Age, Cambridge / New York, Cambridge University Press, 2000.

Dominique Leydet (dir.), « La démocratie délibérative », $\mathrm{n}^{\circ}$ spécial de la revue Philosophiques, vol. 29, n² 2, automne 2002, p. 175-423.

David Luban, « Review of Jon Elster, Closing the Books: Transitional Justice in Historical Perspective », Ethics, n 116, 2006, p. 409-412.

Christian Nadeau, Julie Saada, Guerre juste, guerre injuste. Histoire, théories et critiques, Paris, PUF, 2009. Dennis Sullivan (dir.), The Handbook of Restorative Justice, New York, Palgrave, 1998.

Charles Tilly, Sidney Tarrow, Politique(s) du conflit. De la grève à la révolution, Paris, Presses de Sciences Po, 2008.

John Torpey, Making Whole What Has Been Smashed. On Reparation Politics, Cambridge (Mass.), Harvard University Press, 2006.

Michael Walzer, Guerres justes et injustes. Argumentation morale avec exemples historiques, Paris, Folio Gallimard, 2006.

\section{Fin du texte}

